\title{
СТРАТЕГИЧЕСКИЙ АНАЛИЗ ПЕРСПЕКТИВ ЭКОНОМИЧЕСКОГО ВЗАИМОДЕЙСТВИЯ РОССИИ И КИТАЯ
}

\author{
(c) 2021 Иержати Сайлик \\ аспирант \\ Казанский (Приволжский) федеральный университет, Россия, Казань \\ E-mail: 294696087@qq.com
}

В работе рассматриваются некоторые направления сотрудничества между Россией и Китаем, обусловленные, в том числе - усилением КНР не только на Дальнем Востоке, но и на евразийском континенте в целом. В российской экономике идет постоянное обсуждение российско-китайского сотрудничества. При этом отмечается, большой интерес к экономическому развитию - «китайское чудо», которое привело к мощному прорыву в ряде сфер экономики, осуществленное в начале нового тысячелетия правительством КНР. В ходе исследования были изучены публикации политологов, дипломатов, экономистов, ученых, преподавателей крупных российских и зарубежных вузов, которые работали над анализом специфики сотрудничества РФ и КНР много лет. При этом в научной литературе существуют различные оценки российско-китайского сотрудничества. Впервые термин «стратегическое партнерство» появляется в «Договоре о добрососедстве, дружбе и сотрудничестве между Российской Федерацией и Китайской Народной Республикой». Именно в данном договоре впервые появляется такое понятие, как «стратегическое партнерство». В работе отмечается, что в академической среде неоднозначно оценивают торгово-экономическое сотрудничество России и Китая. Широко распространенно мнение, что изначально при выстраивании партнерских отношений с РФ КНР считала доступ к природным ресурсам Сибири и Дальнего Востока одной из приоритетных задач реализации всех крупномасштабных инвестиционных проектов в рамках сотрудничества.

Ключевые слова: сотрудничество, Китай, Россия, образование, экономика, сотрудничество.

Как показывает проведённый анализ, к 2014 году России и Китаю удалось сохранить высокий уровень двусторонних отношений несмотря на увеличение разрыва между темпами экономического развития двух стран. К 2014 году проблемы нелегальной миграции не осталось, но широкое распространение получил вопрос незаконной трудовой деятельности на Дальнем Востоке. В качестве второго фактора выступает стремительный рост китайской политической мощи, которую приходится учитывать в российских проектах в Азиатско-Тихоокеанском регионе. Постепенно обстановка в мировой политике начинает во многом зависеть от КНР, поэтому Россия заинтересована в мирных отношениях с соседней страной.

Также отдельно выделим влияние на миграционные процессы образовательного аспекта. Многие студенты из РФ и КНР едут учиться в вузы двух стран по совместным программам подготовки специалистов. После окончания обучения они могут получить диплом, который дает им возможность в дальнейшем трудоустроиться по широкому кругу профессий: от научно-технической до лингвистической направленности. Многие устраиваются на работу в качестве переводчиков на совместное производство и учат китайский язык, так как на нем зачастую ведется основная документация. Благодаря подобной академической мобильности налаживаются тесные связи между двумя государствами, происходит обмен научным опытом и подготовка квалифицированных специалистов для Сибири и Дальнего Востока. Особое внимание в исследовании было уделено документам, правительственным заявлениям и программам развития региона.

Среди них можно выделить отдельно «Программу сотрудничества между регионами Дальнего Востока и Восточной Сибири России и Северо-Востока КНР на 2009-2018 гг.». До принятия данной программы предлагаемые меры либо реализовывались частично, либо не принесли практической пользы сотрудничеству. К примеру, Президентскую программу развития Дальнего Востока и Забайкалья на 1996-2005 гг. выпол- 
нили только на 10\%. Такой же неэффективной осталась и вышеупомянутая программа сотрудничества между российскими регионами и провинциями Северо-Восточного Китая. Из этого можно сделать выводы, что на законодательном и исполнительном уровнях миграционные процессы между двумя странами в Сибири слабо урегулированы. Подобные программы неизменно сталкивались с рядом проблем: климатический фактор, наличие больших малоосвоенных территорий, стремление политической элиты активно сотрудничать с Западом, бюрократия и слишком высокая стоимость заявленных проектов.

При этом выдвигаемые документы носили преимущественно декларативный характер и не соответствовали интересам местного населения и бизнес-кругов, не опирались на точные данные. Отметим, что местное население не проявляет по отношению к китайским мигрантам дружелюбия, распространяя ложные слухи, представления и домыслы. Мигрантофобия показывает социальное неблагополучие российских приграничных районов и недовольство политикой на муниципальном уровне.

Отрицательное отношение является следствием неосведомленности, и оно исчезает только под воздействием «народной дипломатии». Она подразумевает участие студентов в программах мобильности, организацию и проведение культурно-массовых мероприятий, командировки, бизнес-встречи между Россией и Китаем. Это способствует налаживанию тесных межгосударственных связей, помогает лучше понимать культуру и менталитет жителей других стран и избавляться от устаревших предрассудков. Доверие на социокультурном уровне дает возможность строить долгосрочные проекты развития сотрудничества во всевозможных областях экономики. Основой антикитайских настроений в сибирском и дальневосточном обществах являются отсутствие длительного исторического опыта взаимодействия с китайскими переселенцами и беспокойство за будущее восточных регионов России, которые оторваны расстоянием от европейской части и испытывают экономические и демографические трудности. Но китайские и российские ученые утверждают, что миграция из КНР не влияет существенно на внутреннюю обстановку и не представляет угрозы национальным интересам РФ.

Постепенно страх перед «китайской колони- зацией» сменяется пониманием, что труд специалистов из соседней страны приносит пользу для развития огромных малоосвоенных сибирских и дальневосточных пространств. По-прежнему острыми проблемами для приезжих китайцев являются суровые условия российской действительности. Они заключаются в больших расстояниях между регионами, тяжелом климате, иной культурной среде, бюрократизме, часто встречающемся непрофессионализме и в высокой стоимости проектов. Программы имеют преимущественно декларативный 89 характер, не соответствуют интересам местных жителей и не опираются на расчеты экспертов. Приоритетом российской внешней политики является восточное направление, которое может способствовать активизации деловых контактов в Азиатско-Тихоокеанском регионе.

С 2010-х гг. приоритетом российской внешней политики является сотрудничество со странами АТР, что наиболее заметно проявилось в активизации деловых контактов с Китаем. Но из-за отсутствия единых согласованных мер по регулированию региональных миграционных процессов немалая часть иностранных рабочих попадает в уязвимое положение, поскольку законодательство ограничено в вопросе реализации их прав. Низкокачественное иммиграционное урегулирование заметно в увеличении вовлеченных китайских граждан в теневой экономике и случаев нелегального пересечения границы.

Власти начали ужесточать административный режим, а это ведёт к увеличению нарушений правопорядка и ущемлению прав мигрантов. При этом невозможно полностью отказаться от услуг китайских рабочих. Поэтому нашей стране необходимо сделать упор на урегулирование миграционной политики. Российско-китайское сотрудничество в сфере трудовой миграции не систематизировано, занимает низкий уровень еще с 1990- х гг. Но демаркация государственной границы и политические взаимоотношения стратегического партнерства позволяют дальше развивать сотрудничество по всем направлениям.

Для упорядочивания потоков китайской рабочей силы на Дальний Восток, необходимо тщательно координировать работу профильных государственных органов на всех уровнях и контролировать миграционные процессы в приграничных районах. Поэтому в России начали раз- 
рабатывать ряд законодательных актов, которые предусматривают упорядочивание приема иностранных специалистов на работу и их взаимоотношения с начальством.

Перспективы сотрудничества в миграционной области зависят от двух факторов. Первым фактором выступает сохранение интереса граждан КНР, особенно из северо-восточных провинций, к рабочей деятельности в регионах Сибири и Дальнего Востока, несмотря на экономический рост и увеличение уровня урбанизации.

Второй фактор - усиление потока квалифицированных рабочих из приграничных районов в европейские страны и США. Особое влияние также оказывает миграционное законодательство России и Китая. Обе стороны начали проводить совместные мероприятия по упорядочиваю миграции из КНР, а также активизировалась борьба с незаконными миграцией и трудовой деятельностью. На межгосударственном уровне начали проводить регулярные консультации в рамках рабочей группы, занимающейся миграционными вопросами. Оптимизация китайской миграции - залог для будущего развития социально-экономического положения приграничных регионов. В качестве приоритета российской политики выступает привлечение отечественных специалистов на Дальний Восток при наличии сбалансированного иммиграционного законодательства.

Россия и Китай ставят цель к 2025 году увеличить товарооборот между собой до 200 миллиардов долларов и достичь уровня, сопоставимого с уровнем торговли Китая с США, Японией и Южной Кореей. Однако это зависит от создания прочной институциональной структуры, которая будет управлять взаимными прямыми инвестициями, финансированием и кредитованием в крупных масштабах и контролировать их осуществление. Сложно однозначно оценить возможность достижения нового уровня экономических отношений между Россией и Китаем, поскольку ситуация в мире нестабильна, международные отношения подвержены постоянным изменениям.

В целом, отношения между двумя странами в экономической сфере очень малы, например, по сравнению с масштабами американо-китайского сотрудничества в этой сфере. Российско-китайские торгово-экономические отношения значительно отстают от темпов, уровня и масштабов развития российско-китайского политического и стратегического диалога. Учитывая общую тенденцию мирового развития, а также характер отношений России с Западом на фоне разворачивающегося украинского кризиса, представляется, что в будущем их отношения сохранят свою нынешнюю логику развития. В этой ситуации наиболее важной задачей для России является расширение партнерства с Китаем.

Как известно, Россия и Китай в настоящее время решают аналогичные проблемы - Россия ставит цель перехода к инновационной модели развития, Китай - создания государства инновационного типа. Для выравнивания торговых отношений с Китаем России необходимо подготовить почву для постепенного перехода к инвестиционной и инновационной модели двусторонней торговли. Продвижение крупных проектов сыграет определенную роль в отношениях между двумя странами: позволит углубить экономическую интеграцию, стимулировать всесторонние взаимовыгодные отношения и будет способствовать формированию единой экономической судьбы Российской Федерации и Китая.

Одним из ключевых моментов российско-китайских экономических отношений может стать трансграничное сотрудничество. России и Китаю следует подумать о региональной экономической интеграции. Соседи могут рассмотреть вопрос о создании зоны свободной торговли и активно формировать модель взаимовыгодных отношений. На двусторонние экономические отношения между Россией и Китаем также оказывает влияние слаборазвитость российско-китайской пограничной инфраструктуры (особенно с российской стороны), что может стать серьезным вызовом для развития сотрудничества между двумя странами. Необходимы совместные усилия для обеспечения наличия современных пунктов пропуска, контрольно-пропускных пунктов, дорог и мостов на границе.

Для решения актуальных вопросов российско-китайских торговых, финансовых и приграничных отношений целесообразно принять меры, указанные на рисунке 1.

Однако здесь встает вопрос о желаниях и намерениях России и Китая. Как известно, в официальных документах они выражают стремление максимально продуктивно сотрудничать, реализовывать новые проекты и развивать доверительное партнерство. Но на практике эти 
желания не всегда исполняются. Сдержанность со стороны Китая, а также ряд противоречий между ним и Россией не позволяют полностью реализовать намеченные планы. Экономическое сотрудничество между Россией и Китаем заметно возросло за последние два десятилетия. Несмотря на рост, экономическая зависимость между странами остается относительно низкой и является скорее более глубокой односторонней зависимостью России от Китая. Экономические отношения в основном характеризовались традиционной торговлей, основанной на срав- нительных преимуществах, тогда как инвестиционные потоки между странами были относительно небольшими.

Поскольку отношения России с западными странами ухудшились, он нацелен на более тесные связи с Китаем. Отношения на высоком уровне, вероятно, лучше, чем когда-либо прежде, но на практике экономическое сотрудничество остается более скромным. Вероятно, оно будет постепенно расширяться, но есть много проблем для углубления отношений и повышения взаимной зависимости.

- Оптимизация структуры российско-китайской торговли за счет увеличения доли машиностроительной продукции и высокой добавленной стоимости товаров;

• Содействие участию российских компаний в реконструкции старых промышленных объектов на северо-востоке и западе Китая;

• Развитие и модернизация трансграничной инфраструктуры;

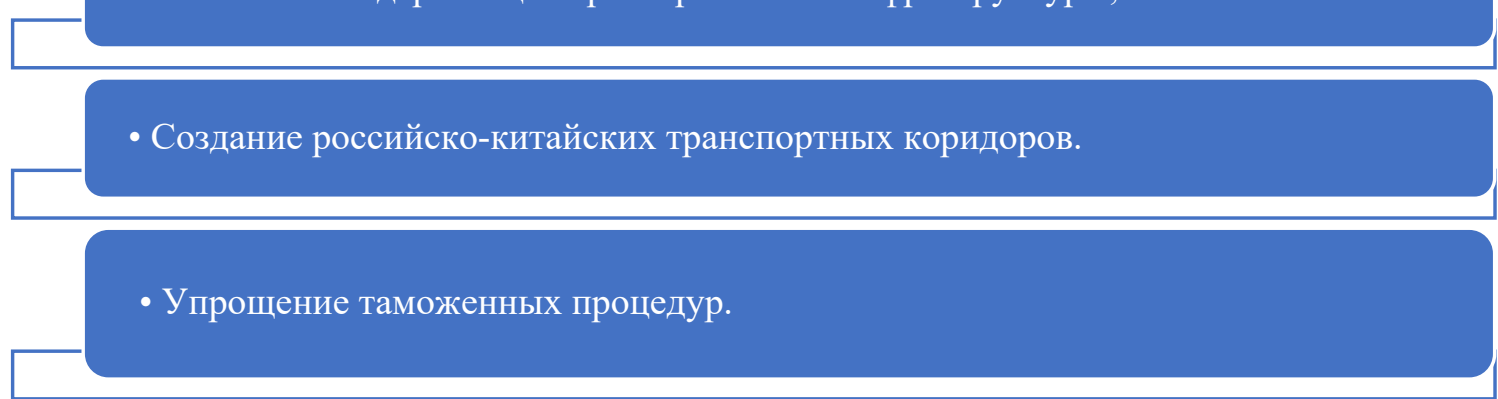

- Увеличение прямых расчетов в национальных валютах в торговле с целью снижения зависимости от доллара США.

• Расширение сотрудничества между Китаем и Россией в банковской сфере, увеличение количества банков, способных проводить торговые и инвестиционные расчеты в юанях и рублях.

• Подготовка высококвалифицированных кадров с экономическим образованием,

\section{Puc. 1. Стратегии развития отношений}




\section{Библиографический список}

1. URL: https://minenergo.gov.ru/node/1026/(Дата обращения: 11.11.2021) - сайт Министерства энергетики Российской Федерации.

2. Чжоу Цзинь. Российский стратегический нефтяной промышленности на основе сотрудничества//исследования мировой экономики,2020 (2). С. 9-12.

3. URL: http://www.forbes.ru/biznes-photogallery/341975-po-druzhbe-i-morem-kuda-techet-nasha-neft?photo=1 (Дата обращения: 06.04.2017) - сайт Forbes.

4. Лю Цинцай. Статус и перспективы экономических отношений Китая и России // Форум Северо-восточной Азии. 2020. No. 3. С. 64.

5. Ли Чжунхай. Развитие энергетического сотрудничества Китая и России./Ли Чжунхай // Друзья руководства. 2020. No. 1. C. 38. 
